\title{
Geografiese ligging beïnvloed vaginale mikrobiese profiele in Suid-Afrikaanse vroue
}

\section{Outeurs:}

Katie Lennard, ${ }^{a, b}$

Smritee Dabee, ${ }^{a, c}$

Shaun L Barnabas, ${ }^{a, c}$

Enock Havyarimana, ${ }^{\mathrm{a}, \mathrm{c}}$

Anna Blakney,

Shameem Z Jaumdally,

Gerrit Botha, ${ }^{\mathrm{a}, \mathrm{b}}$

Nonhlanhla N Mkhize,

Linda-Gail Bekker,

David A Lewise, ${ }^{\mathrm{f}, \mathrm{g}, \mathrm{h}}$

Glenda Gray, ${ }^{i, j}$

Nicola Mulder, a,b

Jo-Ann S Passmore, ${ }^{a, c, k}$

Heather B Jaspan, ${ }^{a, c, l}$

Affiliasies:

a Instituut vir Aansteeklike

Siekte en Molekulêr

Geneeskunde, Universiteit

van Kaapstad, Suid-Afrika

${ }^{b}$ Berekenings Afdeling

Biologie, Departement

Integrasie Biomediese

Wetenskappe, Universiteit

van Kaapstad, Suid-Afrika

'Departement Patologie,

Universiteit van Kaapstad,

Suid-Afrika

${ }^{d}$ Department of Bioengi-

neering, University of

Washington, United States

of America

e Nasionale Instituut vir

Oordraagbare Siektes, Suid-

Afrika

${ }^{f}$ Western Sydney Sexual

Health Centre, Australia

$\mathrm{g}$ Marie Bashir Institute for

Infectious Diseases and

Biosecurity, Australia

h Sydney Medical School,

Westmead, University of

Sydney, Australia

i Perinatale MIV-navorsingseenheid, Universiteit van

die Witwatersrand, Suid-

Afrika

i South African Mediese-

navorsingsraad, Suid-Afrika

${ }^{\mathrm{k}}$ Nasionale Gesondheids-

laboratoriumdiens, Suid-

Afrika

' Seattle Children's Research Institute, Department

of Pediatrics and Global

Health, University of

Washington, United States

of America

Korresponderende outeur: Dr Heather Jaspan

E-pos: hbjaspan@gmail.com

Datums:

Ontvang: $\quad 17 / 09 / 18$

Aanvaar: $\quad 12 / 04 / 19$

Gepubliseer: $12 / 06 / 19$
Vroue van Afrika-afkoms is meer vatbaar vir bakteriële vaginose (BV) in vergelyking met Europese vroue. Beide mikrobiese diversiteit (soos met BV) sowel as spesifieke bakteriële taksa speel ' $n$ rol in seksuele en reproduktiewe gesondheid insluitende MIV vatbaarheid.

Die moontlike rol van geografiese ligging en etnisiteit op die verhouding tussen mikrobiese samestelling en seskuele en reproduktiewe gesondheid bly egter onbekend.

In hierdie studie vergelyk ons dus die vaginale mikrobiota van 16-22-jarige swart, HIVnegatiewe Suid-Afrikaanse vroue van twee geografies-uiteenlopende liggings, beide laeinkomste,hoë bevolkingsdigtheidsgemeenskappe, een in Kaapstad, en een in Johannesburg. Vaginale mikrobiese profiele is bepaal met behulp van $16 \mathrm{~S}$ rRNS volgordebepaling van laterale muur deppers.

Ons pas permutasie variansieanalise (PERMANOVA) toe en vind statisties betekenisvolle assosiasies tussen vaginale mikrobiese samestelling en geografiese ligging $(p=0.02)$, asook met liggaamsmassa-indeks (LMI) $(\mathrm{p}=0.015)$ en menslike papilloomvirus (MPV) risikotipe $(p=0.005)$, maar nie met die voorkoms van een of meer seksueel-oordraagbare infeksies (SOI's) ( $\mathrm{p}=0.053)$ of met hormonale kontrasepsie verbruik nie. $(\mathrm{p}=0.4)$

Geografiese ligging was 'n statisties betekenisvolle determinant van mikrobiese samestelling, ongeag verskille in LMI, SOI status en MPV-risiko tipes tussen Kaapstad en Johannesburg vroue. Geografiese ligging, LMI en MPV-risiko verduidelik gesamentlik $10 \%$ van die variansie in mikrobiese samestelling, met ' $n$ groot persentasie van onbekende oorsprong. Verskeie taksa het statisties betekenisvol verskil in terme van frekwensie of relatiewe vlakke van voorkoms tussen die geografiese liggings.

Ons resultate stel voor dat MIV profilaktiese metodes wat die vaginale mikrobiota teiken die effek van geografiese ligging in ag moet neem.

Vaginal microbiota varies by geographical location in South African women: Women of African descent are more likely to have bacterial vaginosis than women of other ethnicities. Both diversity and likely specific taxa in these microbial communities are important to sexual and reproductive health, such as HIV risk. However, whether the specific taxa also vary by geographical location and/or ethnicity requires further investigation.

Here, we compare the vaginal microbiota of 16-22-year-old black, HIV-negative South African women from two geographically disparate but low-income high population density communities, one in Cape Town (CPT) and one in Johannesburg (JHB). Vaginal microbiota composition was assessed by $16 \mathrm{~S}$ rRNA gene amplicon sequencing of lateral vaginal wall swabs.

Geographical location was significantly associated with vaginal microbiota composition by permutational analysis of variance (PERMANOVA) $(\mathrm{p}=0.02)$, as were body mass index BMI $(p=0.015)$ and human papilloma virus (HPV) risk type $(p=0.005)$, while the presence of one or more sexually transmitted infections (STIs) $(\mathrm{p}=0.053)$ and hormonal contraceptive (HC) usage $(p=0.4)$ were not. Geographical location remained a significant determinant of microbiota composition independent of BMI, STI status and HPV-risk. Together, geographical location, BMI and HPV-risk explained $10 \%$ of the variance in microbiota composition with a large proportion of the variance remaining unexplained. Several taxa differed significantly between geographical location - some by frequency and others by relative abundance.

Our results therefore suggest that HIV prophylactic approaches targeting the vaginal microbiota should be geographically tailored.

Hoe om hierdie artikel aan te haal:

Katie Lennard, Smritee Dabee, Shaun L Barnabas, Enock Havyarimana, Anna Blakney, Shameem Z Jaumdally, Gerrit Botha, Nonhlanhla N Mkhize, Linda-Gail Bekker, David A Lewise, Glenda Gray, Nicola Mulder, Jo-Ann S Passmore, Heather B Jaspan, Geografiese ligging beïnvloed vaginale mikrobiese profiele in Suid-Afrikaanse vroue, Suid-Afrikaanse Tydskrif vir Natuurwetenskap en Tegnologie 38(1) (2019). https://doi.org/10.36303/ SATNT.2019.38.1.685

An English copy of this paper is available online at http://www.satnt.ac.za/index.php/satnt/article/view/685 Kopiereg:

(C) 2019. Authors.

Licensee: Die Suid-Afrikaanse Akademie vir Wetenskap en Kuns. Hierdie werk is onder die Creative Commons Attribution License gelisensieer. 


\section{Inleiding}

Vaginale mikrobiese profiele verskil onder vroue van verskillende etnisiteite (Ravel et al., 2010; Srinivasan et al., 2012; Buvé et al., 2014). Lactobacillus-dominansie is byvoorbeeld baie minder algemeen onder vroue van Afrika-afkoms in vergelyking met Kaukasiese vroue (Ravel et al., 2010; Melis N. Anahtar et al., 2015; Lennard et al., 2017). Hierdie bevinding van relatief lae vlakke van Lactobacilli is ook van toepassing op Afro-Amerikaanse en Hispaanse vroue van Noord Amerika (Zhou et al., 2007; Fettweis et al., 2014; Melis N. Anahtar et al., 2015). Dit is egter nie duidelik tot watter mate geografiese ligging vaginale mikrobiese samestelling onder vroue van dieselfde etnisiteit beïnvloed nie. Beide etnisiteit en geografiese ligging affekteer die voorkoms van bakteriële vaginose (BV) - gekenmerk deur verhoogde vaginale mikrobiese diversiteit en ' $\mathrm{n}$ afname in die relatiewe vlakke van Lactobacilli - met variasie selfs tussen verskillende Afrikalande (Kenyon, Colebunders and Crucitti, 2013). Tog is daar tot dusver nie 'n gedetailleerde beskrywing van vaginale mikrobiese samestelling volgens geografiese liggings nie.

BV word geassosieer met nadelige seksuele en reproduktiewe gesondheidsuitkomste, insluitende SOIs (Wiesenfeld et al., 2003; Gallo et al., 2012; Balkus et al., 2014) asook nadelige geboorte uitkomste (Holst, Goffeng and Andersch, 1994; Leitich and Kiss, 2007; Nelson et al., 2015). Met die ontwikkeling van 'next generation sequencing', is dit nou moontlik om spesifieke taksa met hierdie nadelige uitkomste te assosieer, insluitende voortydige geboortes (Vinturache et al., 2016; Freitas et al., 2018; Tabatabaei et al., 2018) en MIV risiko (McClelland et al., 2018). In 'n studie wat in vyf verskillende lande (Kenya, Uganda, Suid Afrika, Tanzania, Botswana en Zambië) uitgevoer is, vind McClelland et al. spesifieke taksa wat met verhoogde MIV risiko geassosieer word in al vyf lande, met statisties betekenisvolle assosiasies met Parvimonas species tipe 1 en Gemella asaccharolytica en Mycoplasma hominis (McClelland et al., 2018). Nietemin is dit steeds nie bekend of ' $n$ robuste mikrobiese 'vingerafdruk' van MIV risiko, ongeag van geografiese liggings/etnisiteite bepaal kan word nie en of die effek van geografiese ligging van so ' $\mathrm{n}$ belang is dat MIV-risiko-geassosieerde taksa spesifiek tot 'n geografiese ligging bepaal moet word.

In hierdie studie vergelyk ons dus die vaginale mikrobiota van 16-22-jarige swart, HIV-negatiewe Suid Afrikaanse vroue van twee geografies uiteenlopende liggings, beide lae-inkomste, hoë bevolkingsdigtheids gemeenskappe, een in Kaapstad, en een in Johannesburg.

\section{Materiaal en Metodes}

\section{Deelnemerseleksie en monsterversameling}

Deelnemer karakteristieke is voorheen in detail beskryf (Barnabas et al., 2017; Lennard et al., 2017) Kortliks, 298 swart, MIV-negatiewe, 16-22-jarige Suid-Afrikaanse vroue is gewerf uit lae inkomste, hoë bevolkingsdigtheidsgemeenskappe (Kaapstad en Johannesburg), as deel van die Women's Initiative in Sexual Health (WISH) studie (Barnabas et al., 2017).

Goedkeuring vir die studie is verkry van die Navorsingsetiekkomitee van die Universiteit van Kaapstad. Alle deelnemers $\geq 18$ jaar het ingeligte toestemming gegee, terwyl toestemming van ouers vir deelnemers $\leq 18$ jaar verkry is. Deelnemers is ingeskryf indien hulle MIV-negatief, in goeie algemene gesondheid, nie swanger was of besig om te menstrueer was tydens monsterneming nie, en indien hulle nie gedurende die vorige 48 uur onbeskermde seks gehad het nie. Die gebruik van antibiotika in die voorafgaande twee weke was ook 'n uitsluitingskriterium.

Vir deelnemers wat inspuitbare progestien-bevattende voorbehoedmiddels gebruik het is studiebesoeke twee weke na inspuiting geskeduleer, of as hulle geen hormonale voorbehoedmiddels gebruik het nie of indien hulle orale hormonale voorbehoedmiddels gebruik het, is studiebesoeke gedurende die luteale fase van hul menstruele siklus (tussen dag 14-28) geskeduleer. Voor monsterversameling is die volgende uitgevoer: MIV-toetsing en risikoverminderingsberading, 'n MIV Sneltoets (Alere Determine ${ }^{\mathrm{TM}} \mathrm{MIV}-1 / 2 \mathrm{Ag}$ / Ab Combo, Alere, Waltham, MA), 'n swangerskapstoets (U-test Pregnancy Strip, Humor Diagnostica, Pretoria, Suid-Afrika) asook 'n algemene fisiese ondersoek. Genitale monsters is versamel deur 'n weggooibare menstruasiebeker (Softcup ${ }^{\circledR}$ ) vir 'n uur oor die serviks te plaas asook met behulp van vaginale deppers (na verwydering van die Softcup) vir STI toetsing, Nugent-telling en mikrobiese analise.

\section{SOI and BV toetsing}

Vulvovaginale deppers is versamel vir SOI toetsing deur middel van die multipleks polimerase kettingreaksietoets (Chlamydia trachomatis, Neisseria gonorrhoeae, Trichomonas vaginalis, Mycoplasma genitalium, HSV-1 en -2, Haemophilus ducreyi, Treponema pallidum en Lymphogranuloma venereum) soos voorheen beskryf. (Lewis et al., 2012) Bloed is getrek vir MIV Sneltoetse en HSV-2 serologiese toetse en endoservikale deppers is versamel vir MPV toetsing en genotipering deur Roche Linear Array. (Mbulawa et al.)

Die volgende MPV tipes is as hoë risiko MPV beskou: 16, 18, 31, 33, 35, 39, 45, 51, 52, 56, 58, 59, 66, 68 (Jacobs et al., 1997). Vir analise wat na SOI (enige) verwys, word vroue as positief beskou indien hul positief getoets het vir ten minste een van die SOIs (uitsluitende MPV). Laterale wand / posterior forniksdeppers is ingesamel vir Nugent-telling om monsters te klassifiseer as BV-negatief (Nugent 0-3), intermediêr (Nugent 4-6) of positief (Nugent 7-10). Vaginale $\mathrm{pH}$ is gemeet met behulp van $\mathrm{pH}$ kleurvaste toetsstrokies (Macherey-Nagel, Düren, Germany). 


\section{Bakteriële 16S rRNS-geen multiplekspoli- merase kettingreaksie (PKR) amplifikasie en DNS-volgordebepaling}

Deppers is ontdooi en met 'n mengsel van 'mutanolysin' (25kU/ml, Sigma Aldrich), lisosiem $(450 \mathrm{kU} / \mathrm{ml}$, Sigma Aldrich), en lisostafien (4kU, Sigma Aldrich) behandel, en hierna meganies ontwrig met 'n korrelaansluiter (bead adapter). DNS is geïsoleer met behulp van die MoBio PowerSoil DNS isoleringsstel (MoBio, Carlsbad, CA). Die V4 area van die 16S rRNS-geen is geamplifeer met behulp van gewysigde universele inleiers (Pearce, Hilt and Rosenfeld, 2014): 515F (TCG TCG GCA GCG TCA GAT GTG TAT AAG AGA CAG NNN NNG TGC CAG CMG CCG CGG TAA) en 806R (GTC TCG TGG GCT CGG AGA TGT GTA TAA GAG ACA GNN NNN GGA CTA CHV GGG TWT CTA AT), waar NNNNN vyf lukrake nukleotides (vir verhoogde kompleksiteit) aandui; die 5 ' gedeelte is die Illumina Nextera 'adapter', terwyl die DNS-reeks regs van die N'e komplementêr tot die V4 $16 \mathrm{~S}$ rRNA geen is. Dubbele indekse en Illumina DNSvolgordebepalingsaansluiters is toegevoeg met gebruik van die Nextera XT DNA Prep-stel (Illumina).

Gekombineerde duplikaatmonsters is gesuiwer met AMPure XP korrels (Beckman Coulter, Brea, CA, Amerika) en gekwantifiseer met die Picogreen dsDNA-toets (Invitrogen, Carlsbad, CA, Amerika). DNS amplifikasie produkte (amplikons) is gekombineer in ekwimolêre konsentrasies en die gesuiwerde DNS biblioteke, wat elk sowat 100 gekombineerde monsters bevat het, is vir DNSvolgordebepaling op 'n Illumina MiSeq platform (met 300 bp 'paired-end' V3 chemie) gestuur.

Na demultipleksering is DNS basisvolgordes (reads) as volg verwerk: basisvolgordes vir beide rigtings ('forward' en 'reverse' reads) is saamgestel met behulp van die usearch7 sagteware (Edgar, 2010) en 'n maksimum van drie wanpassings per saamgestelde basisvolgorde is toegelaat. Saamgestelde basisvolgordes is met usearch7 gefiltreer, gebaseer op DNS basiskwaliteit (basisvolgordes met E-tellings groter as 0.1 is verwyder); inleier basisvolgordes is verwyder met ' $n$ Python skrip; saamgestelde, gefiltreerde basisvolgordes is kortgeknip by 250bp. Hierna is die saamgestelde basispare ge-derepliseer en die vlak van replikasie vir elke basisvolgorde is genoteer met usearch7. Basisvolgordes is van hoogste na laagste vlak van replikasie gesorteer en de novo groepeer in operasionele taksonomiese eenhede (OTEs), gebaseer op 'n 97\% DNSbasispaar opeenvolgingidentiteit met usearch7. Chimeriese basisvolgordes is opgespoor (teen die Gold databasis) en verwyder met UCHIME (Edgar et al., 2011). Elke basisvolgorde is aan ' $n$ spesifieke OTE identifiseerder toegeken met ' $n$ 97\% opeenvolgingsidentiteitdrumpel. Taksonomiese toekenning is met QIIME 1.8.0 (Caporaso et al., 2010) uitgevoer met die RDP klassifiseerder (vertrouensvlak van 0.5) teen die Greengenes 13.8-verwysings taksonomiese databasis met 'n 97\% opeenvolgingsidentiteitdrumpel. Om spesiesvlak resolusie te verbeter, is ons verteenwoordigende versameling van de novo OTEs teen 'n gemodifiseerde weergawe van die Fettweiss et al. databasis (Fettweis et al., 2012), wat aangepas is om die V4 gedeelte van die 16S rRNA geen te teiken soos voorheen beskryf (Lennard et al., 2017), vegelyk. Vir OTEs waarvoor die BLAST-soektog meer as een spesies opgelewer het (met gelyke identiteits tellings), is taksonomie as volg annoteer: indien die soektog vir 'n spesifieke OTE twee of drie spesies opgelewer het, is die OTE as Genus spesieA_spesieB genoteer, of Genus spesieA_ spesieB_spesieC, onderskeidelik. In die geval van meer as drie spesies waar een spesie duidelik voorheen met vaginale mikrobiota geassosieer is, is die OTE as Genus spesie_cluster geannoteer, waar 'spesie' geselekteer is gebaseer op die meerderheidtreffers, b.v. L. reuteri_cluster dui aan dat die meerderheid van treffers teen $L$. reuteri was, maar dat daar ook verskeie ander spesies met gelyke identiteitstellings deur die soektog opgelewer is.

Monsters met $\geq 5000$ basisvolgordes is vir verdere analise geselekteer. Die OTE-tabel is gestandardiseer om verskille in totale hoeveelheid basisvolgordes tussen verskillende monsters in ag te neem, en verder gefiltreer sodat elke oorblywende OTE ten minste 10 tellings in ten minste $2 \%$ van monsters het of ' $\mathrm{n}$ relatiewe telling van ten minste $0.001 \%$.

\section{Statistiese analise}

Statistiese analise is in $\mathrm{R}$ uitgevoer, met die pakkette phyloseq (McMurdie and Holmes, 2013) vir betadiversiteitanalise, metagenomeSeq (Paulson et al., 2013) vir differensiële vlak toetse, vegan (Oksanen et al., 2016) vir NMDS en RDA analise, en NMF (Gaujoux, 2014) vir geannoteerde hittekaarte.

Permutasie variansieanalise (PERMANOVA) is toegepas met behulp van die adonis en adonis2 funksies uit die R-pakket vegan (Oksanen et al., 2016); vir die adonis funksie is die orde van voorspellerveranderlikes van belang, terwyl die orde van veranderlikes nie die resultate affekteer vir die adonis2 funksie nie. Ons gebruik dus die adonis2 funksie om p-waardes vir individuele veranderlikes te verkry sodat daar geen aannames gemaak is oor die relatiewe belang (volgorde) van veranderlikes nie; en die adonis funksie om aangepaste $R^{2}$ waardes te verkry (wat nie beskikbaar is deur die adonis2 funksie nie). Die aanname vir PERMANOVA van gelykheid van variansies tussen groepe is met die betadisperfunksie van die $\mathrm{R}$ pakket vegan getoets (Oksanen et al., 2016). Hierdie aanname is nagekom indien die Bray-Curtis afstands-matriks gebruik is, maar nie in die geval van UniFrac afstand of geweegde UniFrac afstand nie; ons gebruik dus in hierdie geval Bray-Curtis afstand. In die uiteindelike model is etnisiteit (waar ons vir 24 van die deelnemers nie inligting rakende etnisiteit het nie) uitgesluit aangesien etnisiteit in elk geval nie 'n statistiese betekenisvolle veranderlike was in PERMANOVA in die groep deelnemers vir wie etnisiteit wel bekend was nie. 
Afstand-baseerde oorvloedsanalise (db-RDA) is toegepas op die Bray-Curtis afstandsmatriks met behulp van die dbrda -funksie vanuit die R-pakket vegan en die ordinasie is beperk met betrekking tot geografiese ligging, SOIs (enige), LMI en MPV-risiko (veranderlikes wat nie tydens PERMANOVA betekenisvol was nie, is nie in die uiteindelike model in Figuur 1 ingesluit nie).

Verskille in mikrobiese samestelling tussen groepe van belang is bepaal met metagenomeSeq se MRfulltable-funksie met ' $n$ filter om betekenisvolle resultate te bepaal: saamgestelde taksa (waar OTEs van dieselfde takson bymekaar getel is,) is as betekenisvol verskillend beskou indien die takson ' $n$ veelvoudverandering (beta koëffisiënt) van $\geq 1.5$ gehad het, 'n aangepaste $p$-waarde van $\leq 0.01$ en indien ten minste $20 \%$ van monsters van een of beide groepe daardie spesifieke OTE/takson bevat OF indien Fisher se toetsresultate betekenisvol was (na aanpassing vir veelvuldige toetse).

Die verspreiding van saamgestelde OTEs/taksa (waar OTEs van dieselfde takson bymekaar getel is op die laagste taksonomiese vlak beskikbaar vir elke OTE) word in Figuur 2 opgesom. Die taksa wat as mees volop beskou word onder die deelnemers aan hierdie studie is as volg geselekteer: vir elke deelnemer is OTE-tellings van hoog-na-laag sorteer en die taksa wat kumulatief die eerste $50 \%$ van die totale OTEtellings vir daardie deelnemer uitmaak is genoteer. Hierdie proses het ' $n$ lys van 28 unieke taksa oor alle deelnemers opgelewer, en hierdie lys is verder beperk tot taksa wat as 'volop' beskou is in ten minste twee deelnemers, wat die lys tot 12 verminder het (Figuur 2).

Random forest analise is toegepas op saamgestelde taksa met behulp van die R-pakkette randomForest (Liaw and Wiener, 2002) en ROCR (Sing et al., 2005) om vas te stel watter taksa die beste voorspellers van geografiese ligging is. Die volle datastel is gebruik om die Random forest-model te leer (die data is dus nie in leer- en toetstelle verdeel nie).

\section{Resultate}

Vaginale mikrobiese profiele is bepaal met behulp van 16S rRNS-volgordebepaling van laterale wand deppers vir 102 vroue uit Kaapstad en 79 vroue uit Johannesburg (Tabel 1). Die twee groepe het goed vergelyk in terme van ouderdom (mediaan 18 jaar vir beide liggings). Hormonale kontrasepsiegebruik het betekenisvol verskil met $100 \%$ van Kaapstad-vroue teenoor slegs $14 \%$ van Johannesburg-vroue wat een of ander vorm van hormonale kontrasepsie gebruik het, waarskynlik as gevolg van verskille in werwingsprosesse tussen die twee liggings (Kaapstad deelnemers is gewerf deur 'n gesinsbeplanningskliniek, terwyl Johannesburg deelnemers uit die algemene populasie gewerf is).

Kaapstad-vroue het hoër voorkomste van BV (55 vs. 35\%) en SOIs ( 59 vs. $24 \%$ ) gehad, asook hoër LMIs (25.4 vs. 22.5 ) en hoër vlakke van genitale inflammasie. Kaapstad-vroue het meer homogene etnisiteit as Johannesburg-vroue gehad (Tabel 1).

TABEL 1: Deelnemerkenmerksamevatting volgens geografiese ligging

\begin{tabular}{|c|c|c|c|}
\hline Kenmerk & Kaapstad (N=102) & Johannesburg ( $N=79$ ) & P waarde \\
\hline$\overline{\text { Mediaan ouderdom (jaar) }}$ & 18 & 18 & 0.6 \\
\hline BV voorkoms, n (\%) & & & 0.008 \\
\hline BV positief & $56(55)$ & $28(35)$ & \\
\hline BV intermediêr & $7(7)$ & $15(19)$ & \\
\hline BV negatief & $39(38)$ & $36(46)$ & \\
\hline Nugent telling (mediaan) & 8 & 4 & 0.01 \\
\hline SOI (enige), n (\%) & $60(59)$ & $19(24)$ & $2.7 e-6$ \\
\hline C. trachomatis & $45(44)$ & $13(17)$ & $1 \mathrm{e}-4$ \\
\hline N. gonorrhoeae & $14(14)$ & $4(5)$ & 0.08 \\
\hline T. vaginalis & $6(6)$ & $3(4)$ & 0.7 \\
\hline M. genitalium & $4(4)$ & $2(3)$ & 0.7 \\
\hline$H S V-2, n(\%)$ & $6(6)$ & $1(1)$ & 0.1 \\
\hline MPV risiko, n (\%) & & & 0.3 \\
\hline Hoog & & $42(41)$ & $33(42)$ \\
\hline Lag & $29(28)$ & $15(19)$ & \\
\hline Negatief & $31(30)$ & $31(39)$ & \\
\hline Hormonale kontraspesie ${ }^{\&}, \mathrm{n}(\%)$ & & & $<2.2 \mathrm{e}-16$ \\
\hline$D M P A$ & $19(19)$ & $9(12)$ & \\
\hline Implanon & $8(8)$ & $0(0)$ & \\
\hline Nur isterate & $70(69)$ & $12(15)$ & \\
\hline Kontraseptiewe pil & $4(4)$ & $6(8)$ & \\
\hline Manlike kondoom & $0(0)$ & $36(46)$ & \\
\hline Nuvaring & $1(1)$ & $0(0)$ & \\
\hline Inspuitbare kontrasepsie (tipe onbekend) & $0(0)$ & $5(6)$ & \\
\hline Geen & $0(0)$ & $10(13)$ & \\
\hline Gebruik hormonale kontrasepsie, $n(\%)$ & & & $<2.2 \mathrm{e}-16$ \\
\hline Enige hormonale kontrasepsie & $102(100)$ & $32(41)$ & \\
\hline Kondome/geen & $0(0)$ & $46(59)$ & \\
\hline \multicolumn{4}{|l|}{ Ethnicity", n (\%) } \\
\hline Xhosa & $94(99)$ & $17(28)$ & $<2.2 \mathrm{e}-16$ \\
\hline Ander ${ }^{Q}$ & $1(1)$ & $44(72)$ & \\
\hline LMI (mediaan) & 25.3 & 22.5 & 0.04 \\
\hline
\end{tabular}

\&Kontrasepsie inligting was vir een vrou onbekend;" Etnisiteitsinligting was vir 25 vroue onbekend. 
PERMANOVA is toegepas om faktore te identifiseer wat vaginale mikrobiese profiele beïnvloed. Faktore wat in ag geneem is sluit in etnisiteit, ouderdom, hormonale kontrasepsie gebruik (ja/nee), die voorkoms van een of meer SOIs, uitsluitende MPV (ja/nee), MPV-risiko (hoog/ laag/negatief), geografiese ligging en LMI. Etnisiteit is nie in die uiteindelike model ingesluit nie aangesien daar 24 deelnemers was vir wie ons nie etnisiteitsinligting gehad het nie, en aangesien etnisiteit nie 'n statistiese betekenisvolle veranderlike was in PERMANOVA vir deelnemers vir wie etnisiteit wel bekend was nie. Ouderdom is ook nie in die uiteindelike model ingesluit nie aangesien daar geen betekenisvolle verskil in ouderdom tussen Kaapstad en Johannesburg vroue was nie (Tabel 1). Faktore wat wel statisties betekenisvol met vaginale mikrobiese samestelling geassosieer was, sluit in geografiese ligging $(p=0.02)$, LMI $(p=0.015)$ en MPV-risiko tipe $(p=0.005)$. In teenstelling was daar geen statisies betekenisvolle verhouding tussen vaginale mikrobiese samestelling en die voorkoms van een of meer SOIs $(p=0.053)$ of met hormonale kontrasepsieverbruik $(\mathrm{p}=0.4)$ nie. Geografiese ligging, LMI en MPV-risiko verduidelik gesamentlik $10 \%$ van die variansie in mikrobiese samestelling, met die meerderheid van onbekende oorsprong.

Aangesien daar 'n groot verskil in hormonale kontrasepsie gebruik tussen Kaapstad-en Johannesburg-vroue was (Tabel 1), is PERMANOVA ook toegepas slegs op deelnemers wat hormonale kontrasepsie gebruik het (uitsluitende die wat slegs kondome of geen kontrasepsie gebruik het nie). Geografiese ligging ( $p=0.02)$, LMI ( $p=0.03$ ) en MPV-risiko ( $p=0.05)$ was weereens statisties betekenisvol geassosieer met vaginale mikrobiese samestelling, terwyl die voorkoms van SOI's nie betekenisvol was nie $(\mathrm{p}=0.7)$.

Die uitkomste van db-RDA (wat toegepas is op die BrayCurtis afstandsmatriks van mikrobiese profiele) het die PERMANOVA resultate bevestig (Figuur 1); db-RDA is 'n beperkte hoofkoordinaatsanalise (PCoA) wat gebruik maak van nie-Euklidiese ongelyksoortigheids-indekse soos

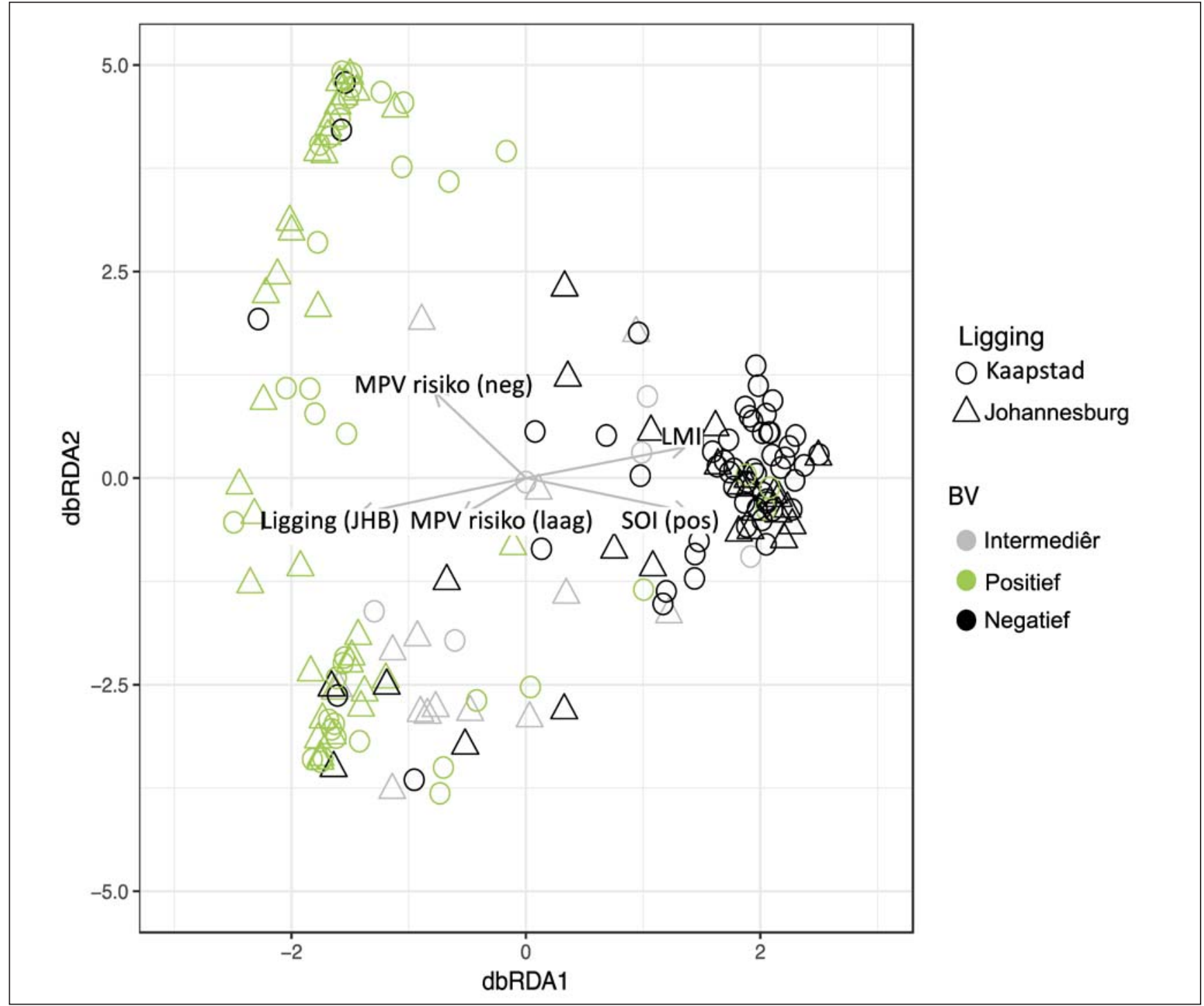

FIGUUR 1: dbRDA analise van die Bray-Curtis afstandsmatriks volgens geografiese ligging, SOls (positief/negatief), MPV-risiko (hoog /lag/negatief) en LMI; JHB (Johannesburg); neg (negatief); pos (positief) 


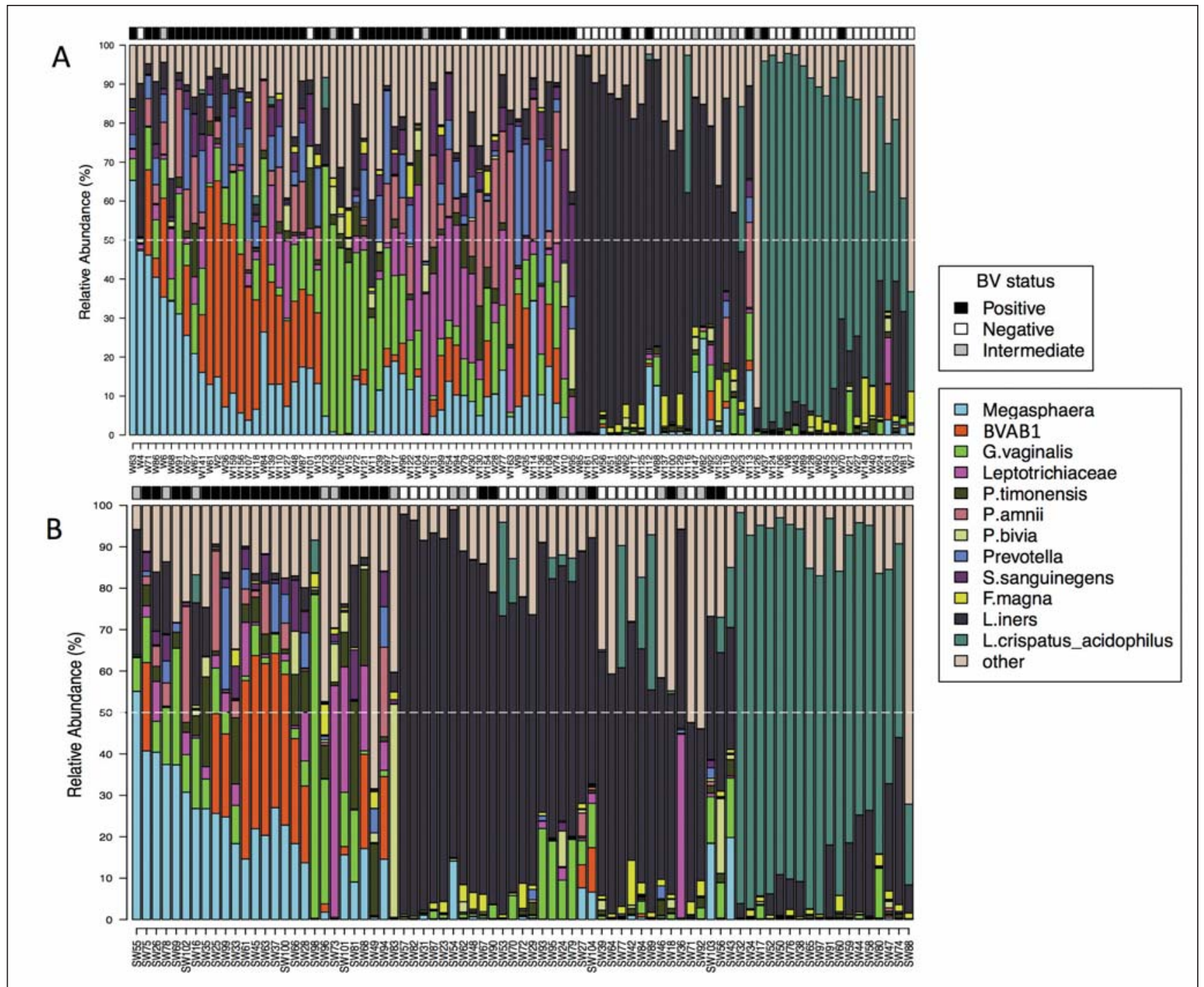

FIGUUR 2: Opsomming van individuele vaginale mikrobiese profiele, gegroepeer volgens die mees omvattende taksa in A) Kaapstad en B) Johannesburg. Taksa wat in die figuur gelys is, is geselekteer uit die taksa wat die eerste $50 \%$ van elke deelnemer se profiel opmaak nadat taksa volgens tellings georden is. Deelnemers (horisontaal) is gegroepeer volgens hul mees dominante takson, in dieselfde orde as taksa wat regs van die figuur gelys is (bv. deelneemers vir wie Megasphaera die mees dominante takson was, is aan die linkerkant van die figuur saam gegroepeer (ligblou)). Ander: die kumulatiewe tellings van alle oorblywende taksa wat nie hier gelys is nie. Swart, wit en grys boksies dui onderskeidelik op BV+, BV- en BV- intermediêre status.

Bray-Curtis, en daarom veral geskik is vir $16 \mathrm{~S}$ rRNA-geen mikrobiota data. Faktore wat ingesluit is in die db-RDAordinasie sluit in geografiese ligging, SOIs uitsluitende MPV (ja/nee), MPV-risiko en LMI (d.w.s faktore wat betekenisvol tydens PERMANOVA was, met SOIs $\mathrm{p}=0.053)$. Om verder die verhouding tussen geografiese ligging en mikrobiese samestelling te bevestig, is faktore wat betekenisvol verskil tussen geografiese liggings (SOIs (positief/negatief), MPV-risiko en LMI) uit die db-RDAmodel verwyder, waarna geografiese ligging steeds 'n betekenisvolle verhouding met mikrobiese samestelling gehad het $(\mathrm{p}=0.02)$.

Die mees dominante taksa word in Figuur 2 volgens geografiese ligging opgesom.

Om vas te stel watter taksa betekenisvol verskil tussen Kaapstad en Johannesburg, is differensiële-vlak toetse toegepas m.b.v. die R-pakket metagenomeSeq. Die analise is uitgevoer op saamgestelde taksa (gegroepeer op laagste moontlike taksonomiese vlak (sien Metodes vir verdere besonderhede). Agtien taksa het betekenisvol verskil tussen Kaapstad en Johannesburg - óf in terme van vlakke óf in terme van frekwensie van voorkoms (Figuur 3). Taksa wat betekenisvol meer algemeen (persentasie monsters wat wel die spesifieke takson bevat) in Kaapstad was sluit in Bifidobacterium, Prevotella pallens, Pseudomonas, Elizabethkingia meningoseptica, Brevundimonas, Mycoplasmataceae en Chryseobacterium, terwyl Lactobacillus coleohominis, Lactobacillus reuteri_cluster, Morganella morganii, terwyl Varibaculum cambriense meer algemeen in Johannesburgvroue was. Taksa wat teen soortgelyke frekwensies in Kaapstad -en Johannesburg -vroue voorgekom het, maar verskil het in terme van die vlak van kolonisasie (tellings) sluit in Leptotrichiaceae, Sneathia sanguinegens, P. amnii, Prevotella en BVAB3 (Mageeibacillus indolicus) - al hierdie taksa het teen relatief hoër vlakke in Kaapstad voorgekom. 


\section{JOHANNESBURG VS KAAPSTAD}
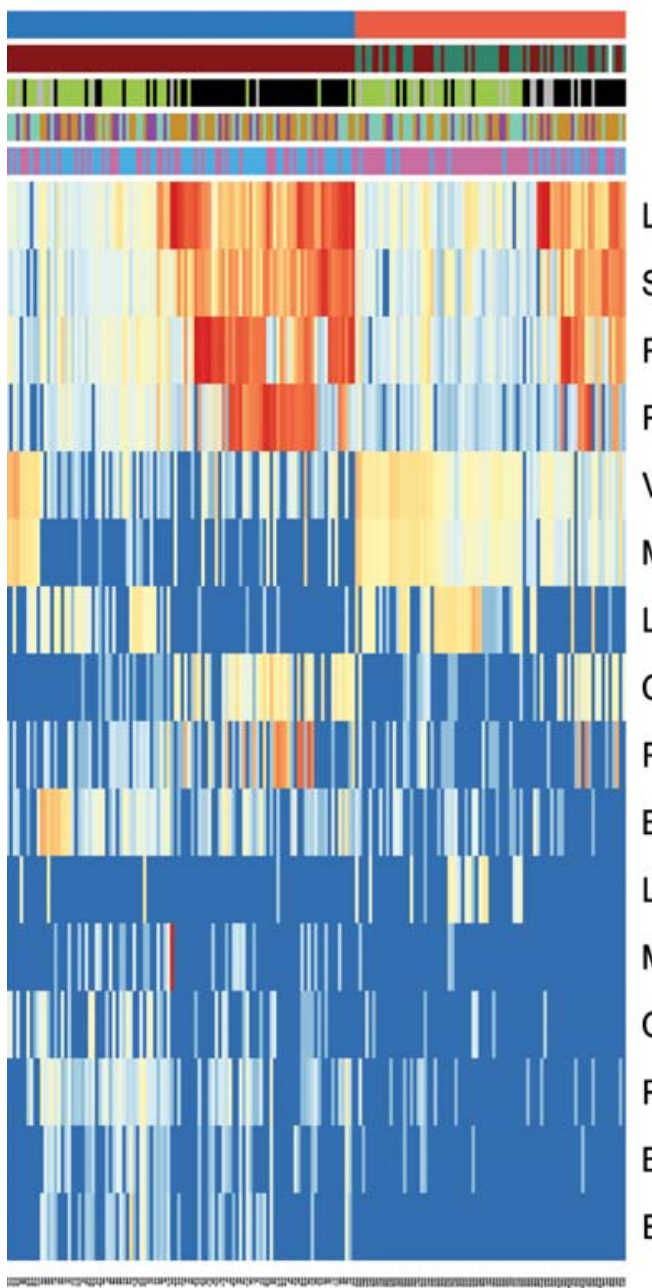

Leptotrichiaceae

S.sanguinegens

P.amnii

Prevotella

V.cambriense

M.morganii

L.reuteri_cluster

C.BVAB3_M_indolicus

P.pallens

Bifidobacterium

L.coleohominis

Mycoplasmataceae

Chryseobacterium

Pseudomonas

Brevundimonas

E.meningoseptica

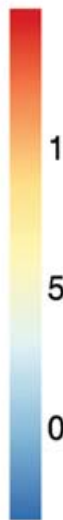

Ligging

Johannesburg

10

Kaapstad

Hormonale

kontrasepsie

$\square \mathrm{Ja}$

Nee

5

\section{BV}

Positief

Negatief

Intermediêr

MPV risiko

Hoog

Laag

Negatief

SOI

Positief

Negatief

FIGUUR 3: Hittekaart van taksa (gegroepeer op laagste moontlike taksonomiese vlak) wat met betekenisvol verskillende vlakke of frekwensies in Kaapstad -teenoor Johanneseburg-vroue voorkom (aangepaste $\mathrm{p}$-waarde $\leq 0.01$, koëffisiënt $\geq 1.5$, taksa teenwoordig in $\geq 20 \%$ van monsters in ten minste een van die twee groepe wat vergelyk is); individue (kolomme) is eers volgens geografiese ligging gesorteer, waarna hierargiese trosvorming binne elke ligging toegepas is; hittekaart skaal: log2getransformeerde gestandardiseerde tellings.

Met behulp van random forest-analise is M. morganii en $V$. cambriense as die mees invloedryke taksa in die onderskeid tussen Kaapstad-en Johannesburg-vroue geidentifiseer (area onder die kurwe $=0.95$, positiewe voorspellingswaarde $=0.91$, negatiewe voorspellingswaarde $=0.89$ ).

\section{Bespreking}

Vaginale mikrobiese profiele verskil onder vroue van verskillende etnisiteite en geografiese liggings. In hierdie studie demonstreer ons verskille in relatiewe vlakke en frekwensie van kolonisasie van spesifike vaginale mikrobiota in Afrika-vroue van soortgelyke ouderdomme en sosio-ekonomiese agtergronde vanuit Kaapstad en Johannesburg. Hierdieverskillekonnievolledig verduidelik word deur ander faktore wat verskil het tussen die twee liggings nie, insluitende hormonale kontrasepsiegebruik, etnisiteit, LMI, MPV-risiko en die voorkoms van SOI's. Saam het geografiese ligging, LMI en MPV-risiko 10\% van die variansie in mikrobiese samestelling verklaar, met 'n groot proporsie van die variansie dus onverklaar.

McClelland et al. het in vyf verskillende Afrika-lande gevind dat die vlakke van sekere taksa met latere MIV serokonversie geassosieer is. In 'n sensitiwiteitsanalise wat frekwensie van kolonisasie gebruik, is sekere taksa nietemin duidelik van grotere belang in spesifieke geografiese liggings. Die voorkoms van Mycoplasma hominis speel byvoorbeeld 'n rol in MIV risiko in Keniaanse sekswerkers, maar nie in serodiskordante paartjies uit Uganda en Suid-Afrika nie, waar Gemella en Parvimonas van groter belang was (McClelland et al., 2018). In 'n studie van vroue van KwaZulu Natal het Williams et al gevind dat Prevotella bivia-vlakke die beste voorspeller van latere MIV serokonversie was (Williams, AIDS Conference 2016). In 'n soortegelyke studie in KwaZulu Natal, maar in jonger vroue, het Gossman et al gevind dat relatiewe vlakke van P. melaninogenica en Veillionella montpellierensis die beste 
voorspellers van latere MIV serokonversie was (Gosmann et al., 2017).

Verskeie studies oor die verhouding tussen vaginale mikrobiota en voortydige geboortes het gevind dat Lactobacillus-dominante vaginale mikrobiota beskermend is, maar geen taksa is tot dus ver konsekwent met 'n verhoogde risiko van hierdie uitkomste geassosieer nie (Dingens 2016, Romero 2014). Freitas et al het gevind dat Mollicute-vlakke 'n potensiële risiko faktor is vir voortydige geboortes (Freitas et al., 2018). Verder, alhoewel Gardnerella en Ureaplasma relatiewe vlakke goeie voorspellers van voortydige geboortes in ' $n$ oorwegend Kaukasiese studiegroep uit Kalifornie was, kon Callahan et al nie hierdie bevindinge repliseer in ' $\mathrm{n}$ oorwegend Afro-Amerikaanse studiegroep uit Alabama nie (Callahan et al., 2017).

Ten slotte, alhoewel daar moontlik ' $n$ handvol taksa is wat konsekwent met nadelige seksuele en reproduktiewe gesondheidsuitkomste geassosieer kan word ongeag van geografiese ligging, dui ons resultate aan dat verskeie relevante taksa moontlik gemis sal word indien geografiese konteks nie in ag geneem word nie. Dit is nie bekend wat die rede vir hierdie geografiese verskille in vaginale mikrobiese samestelling mag wees nie - omgewings/ gemeenskaps mikrobiese samestelling gedurende vroeë lewe asook vestiging van mikrobiota speel waarskynlik ' $n$ belangrike rol. Ongeag die oorsprong van hierdie verskille beklemtoon ons resultate die noodsaaklikheid van geografies-relevante mikrobies-gebaseerde diagnostiese toetse en terapeutiese middels, selfs binne dieselfde land.

\section{Erkennings}

Hierdie studie is ondersteun deur toekennings van die European and Developing Countries Clinical Trials Partnership (EDCTP) Strategic Primer toekenning $[S P \bullet 2011 \bullet 41304 \bullet 038$ ] en die Suid Afrikaanse Departement vir Wetenskap en Tegnologie [DST/CON 0260/2012]. KL was ondersteun deur die Nasionale Navorsingstigting (NRF) en die Suid-Afrikaanse Akademie vir Wetenskap en Kuns. HBJ was deels ondersteun deur toekenning K08HD069201. SLB was ondersteun deur die HIV Vaccine Trials Network SHAPe Program, die Fogarty Stigting en die Suid-Afrikaanse Mediese Navorsingsraad (MRC). SD was ondersteun deur die NRF. Die DTHF gee ook erkenning vir die ondersteuning van ViiV gesondheidsorg in hulle YouthShield program. PHRU was ook ondersteun deur befondsing van die MRC. Ons bedank die WISH studie spanne, veral Ms Pinky Ngobo, Sr Nozipho Hadebe, Sr Janine Nixon, en al die jong vroue wat aan hierdie studie deelgeneem het. Ons bedank Prof. Lynn Morris, David Lewis, Venessa Maseko en Raveshni Durgiah van die Nasionale Instituut vir Oordraagbare Siektes vir hulle hulp met monsterprosessering. Dataprosessering is uitegevoer met gebruik van fasiliteite verskaf deur die Universiteit van Kaapstad se ICTS High Performance Computing span: http:/ /hpc.uct.ac.za

\section{Verwysings}

Anahtar MN, et al. 2015. Cervicovaginal bacteria are a major modulator of host inflammatory responses in the female genital tract. Immunity. Elsevier Inc., 42(5), pp. 965-976. doi: 10.1016/j.immuni.2015.04.019.

Balkus JE, et al. 2014 Bacterial vaginosis and the risk of trichomonas vaginalis acquisition among HIV-1-negative women. Sexually transmitted diseases, 41(2), pp. 123-8. doi: 10.1097/OLQ.0000000000000075.

Barnabas SL, et al. 2017. Converging epidemics of sexually transmitted infections and bacterial vaginosis in southern African female adolescents at risk of HIV. International Journal of STD \& AIDS.

Buvé A et al. 2014. The vaginal microbiota and susceptibility to HIV. Aids, 28(16), pp. 2333-2344. doi: 10.1097/QAD.0000000000000432.

Callahan BJ et al. 2017. Replication and refinement of a vaginal microbial signature of preterm birth in two racially distinct cohorts of US women. Proceedings of preterm birth in two racially distinct cohorts of US women. Proceedings
of the National Academy of Sciences, 114(37), p. 201705899. doi:10.1073/ of the National Acad
pnas.1705899114.

Caporaso JG, et al. 2010. QIIME allows analysis of high-throughput community sequencing data. Nature Methods, 7(5), pp. 335-336.

Edgar RC, et al. 2010. Search and clustering orders of magnitude faster than BLAST Bioinformatics, 26(19), pp. 2460-2461. doi: 10.1093/bioinformatics/btq461.

Edgar RC, et al. 2011. UCHIME improves sensitivity and speed of chimera detection. Bioinformatics, 27(16), pp. 2194-2200. doi: 10.1093/bioinformatics/btr381.

Fettweis JM, et al. 2012. Species-level classification of the vaginal microbiome. BMC genomics. BioMed Central Ltd, 13(Suppl 8), p. S17. doi: 10.1186/1471-216413-S8-S17.

Fettweis JM, et al. 2014. Differences in vaginal microbiome in African American women versus women of European ancestry. Microbiology (United Kingdom), 160(2014, pp. 2272-2282. doi: 10.1099/mic.0.081034-0.

Freitas AC, et al. 2018. Increased richness and diversity of the vaginal microbiota and spontaneous preterm birth. Microbiome, 6(1), pp. 1-15. doi:10.1186/ s40168-018-0502-8.

Gallo MF, et al. 2012. Bacterial vaginosis, gonorrhea, and chlamydial infection among women attending a sexually transmitted disease clinic: a longitudinal analysis of possible causal links. Annals of Epidemiology, 22(3), pp. 213-220. doi: 10.1016/j.annepidem.2011.11.005.

Gaujoux R, et al. 2014. Generating heatmaps for Nonnegative Matrix Factorization pp. 1-11.

Gosmann C, et al.2017. Lactobacillus-deficient cervicovaginal bacterial communities are associated with increased HIV acquisition in young South African women. Immunity. Elsevier Inc., 46, pp. 1-9. doi: 10.1016/j.immuni.2016.12.013.

Holst E, Goffeng AR, Andersch B, et al. 1994. Bacterial vaginosis and vaginal microorganisms in idiopathic premature labor and association with pregnancy outcome. Journal of Clinical Microbiology, 32(1), pp. 176-186.

Jacobs MV, et al. 1997. A general primer GP5+ / GP6 + -mediated PCR-enzyme immunoassay method for rapid detection of 14 high-risk and 6 low-risk human papillomavirus genotypes in cervical scrapings. Journal of Clinical Microbiology, 35(3), p. 791

Kenyon C, Colebunders R, Crucitti T, et al. 2013. The global epidemiology of bacteria vaginosis: A systematic review. American Journal of Obstetrics and Gynecology. Elsevier Inc, 209(6), pp. 505-523. doi: 10.1016/j.ajog.2013.05.006.

Leitich $\mathrm{H}$, Kiss $\mathrm{H}$, et al. 2007. Asymptomatic bacterial vaginosis and intermediate flora as risk factors for adverse pregnancy outcome. Best Practice and Research: Clinical Obstetrics and Gynaecology, 21(3), pp. 375-390. doi: 10.1016/j.bpobgyn.2006.12.005.

Lennard K, et al. 2017. Microbial composition predicts genital tract inflammation and persistent bacterial vaginosis in adolescent South African women. Infection and Immunity, (October), p. IAI.00410-17. doi: 10.1128/IAI.0041017.

Lewis DA, et al. 2012. Prevalence and associations of genital ulcer and urethra pathogens in men presenting with genital ulcer syndrome to primary health care clinics in South Africa. Sexually transmitted diseases, 39(11), pp. 880-5. care clinics in South Africa. Sexually tran
doi: 10.1097/OLQ.0b013e318269cf90.

Liaw A, Wiener M, et al. 2002. Classification and regression by random forest. $R$ news, 2(3), pp. 18-22. doi: 10.1177/154405910408300516.

McClelland RS, et al. 2018. Evaluation of the association between the concentrations of key vaginal bacteria and the increased risk of HIV acquisition in African women from five cohorts: A nested case-control study. The Lancet Infectious Diseases. Elsevier Ltd, 3099(18), pp. 1-11. doi: 10.1016/S14733099(18)30058-6.

McMurdie PJ, Holmes S, et al. 2013. Phyloseq: an R package for reproducible interactive analysis and graphics of microbiome census data. PloS one, 8(4), p. e61217. doi: 10.1371/journal.pone.0061217.

Nelson DB, et al. 2015. First trimester levels of BV-associated bacteria and risk of miscarriage among women early in pregnancy. Maternal and Child Health Journal. Springer US, 19(12), pp. 2682-2687. doi: 10.1007/s10995-015-1790-2. 
Oksanen AJ, et al. 2016. Package "vegan".

Paulson JN, et al. 2013. Differential abundance analysis for microbial markergene surveys. Nature Methods, 10(12), pp. 1200-2. doi: 10.1038/nmeth.2658.

Pearce MM, Hilt EE, Rosenfeld AB, et al. 2014. The female urinary microbiome: a comparison of women with and without urgency urinary incontinence. $\mathrm{mBio}$ 5(4), pp. 1-12. doi: 10.1128/mBio.01283-14. Editor.

Ravel J, et al. 2010. Vaginal microbiome of reproductive-age women. PNAS, 108, pp. 4680-4687. doi: 10.1073/pnas.1002611107/-/DCSupplemental.www.pnas. org/cgi/doi/10.1073/pnas.1002611107.

Sing T, et al. 2005. ROCR: Visualizing classifier performance in R. Bioinformatics, 21(20), pp. 3940-3941. doi: 10.1093/bioinformatics/bti623.

Srinivasan S, et al. 2012. Bacterial communities in women with bacterial vaginosis: high resolution phylogenetic analyses reveal relationships of microbiota to clinical criteria. PloS one, 7(6). doi: 10.1371/journal.pone.0037818.
Tabatabaei N, et al. 2018. Vaginal microbiome in early pregnancy and subsequent risk of spontaneous preterm birth: a case-control study. BJOG: An International Journal of Obstetrics \& Gynaecology, pp. 8-11. doi:10.1111/1471-0528.15299.

Vinturache $A E$, et al. 2016. Maternal microbiome - A pathway to preterm birth Seminars in Fetal and Neonatal Medicine, 21(2), pp. 94-99. doi: 10.1016/j. siny.2016.02.004

Wiesenfeld HC, et al. 2003. Bacterial vaginosis is a strong predictor of Neisseria gonorrhoeae and Chlamydia trachomatis infection. Clinical infectious diseases: an official publication of the Infectious Diseases Society of America, 36(5), pp. 663-668. doi: 10.1086/367658.

Zhou X, et al. 2007. Differences in the composition of vaginal microbial communities found in healthy Caucasian and black women. ISME Journal, 1(2), pp. 121-133. doi:10.1038/ismej.2007.12. 